\title{
Tympanic Membrane Haematoma in a Rivaroxaban- Treated Patient: A Case Report
}

\section{Hematoma Timpânico em Doente sob Rivaroxabano: Um Caso Clínico}

\author{
Inês SALDANHA $\triangle^{1,2}$, Ricardo MATOS ${ }^{1,2}$, Tiago ÓRFÃO ${ }^{1,2}$, Margarida SANTOS ${ }^{1}$
}

Acta Med Port 2019 Jun;32(6):469-470 - https://doi.org/10.20344/amp.9397

\begin{abstract}
New generation oral anticoagulants - rivaroxaban, apixaban and edoxaban - represent an important medical achievement. Their therapeutic effectiveness and ease of use make them essential in the management of thromboembolic conditions. However, as warfarin, they have known haemorrhagic risks. This paper reports the case of a 50-year-old female who presented with ear pain and spontaneous blood discharge in her right ear, after a two-week treatment with rivaroxaban. The physical examination revealed a spontaneous tympanic haematoma in the inferior quadrants, adjacent to the umbus. She denied any manipulation of the ear canal. Our goal is to alert for a presumable side effect of this drug in clinical practise.
\end{abstract}

Keywords: Hematoma/etiology; Rivaroxaban/adverse effect; Tympanic Membrane

\section{RESUMO}

A nova geração de anti-coagulantes orais - rivaroxabano, apixabano e edoxabano - constitui um avanço significativo na medicina. Estes fármacos têm, atualmente, um papel fundamental no tratamento de doenças tromboembólicas, pela sua facilidade de administração. No entanto, tal como a varfarina, têm efeitos adversos, nomeadamente aqueles relacionados com o risco hemorrágico. Neste artigo, apresentamos o caso de uma doente de 50 anos de idade, do género feminino, que se apresentou no serviço de urgência com otalgia e otorragia espontânea à direita, após duas semanas de tratamento com rivaroxabano em dose profilática. No exame objetivo, destacava-se a presença de hematoma nos quadrantes inferiores do tímpano, adjacente ao umbus. Não havia história de manipulação do ouvido. O nosso objetivo é alertar para um provável efeito adverso deste fármaco, na prática clínica.

Palavras-chave: Hematoma/etiologia; Membrana Timpânica; Rivaroxabano/efeitos adversos

\section{INTRODUCTION}

For more than 50 years, vitamin $\mathrm{K}$ antagonists represented the only class of therapy available for long-term anticoagulation.

Recently, new oral anticoagulants have been developed, such as rivaroxaban, edoxaban and apixaban. Rivaroxaban's mechanism of action involves factor Xa inhibition, disabling the formation of thrombin as the extrinsic and intrinsic pathways of the coagulation cascade converge.

New oral anticoagulants have outstanding advantages as they do not require monitoring, can be given at fixed doses, do not involve dietary adjustments and have scarce pharmacologic interactions. ${ }^{1-4}$ Rivaroxaban is the most extensively studied. Several initial trials report its efficacy and safety. 5,6 Despite all the benefits associated to the new anticoagulants, there are inevitable risks related to bleeding. The precise risk of haemorrhagic complications remains unclear as the three major prospective trials assessing the safety of these drugs are still running..$^{7-9}$ To the authors' knowledge, tympanic membrane haemorrage associated with rivaroxaban has never been mentioned in the literature, therefore the present case report should bring attention to this possible side effect.

\section{CASE REPORT}

We describe a case report of a 50-year-old Caucasian woman who was observed in the emergency department of our institution due to complaints of acute onset ear pain and spontaneous bloody discharge in the right ear, for five hours. She had no other otologic symptoms.

The patient was prescribed rivaroxaban at a dose of $10 \mathrm{mg}$ once daily. She had completed two weeks of treatment in the sequence of an elective saphenectomy. She had no relevant prior medical history and was not taking any additional medication.

Physical examination revealed a millimetric tympanic haematoma in the inferior quadrants, adjacent to the umbus (Fig. 1). She denied any manipulation of the ear canal. The Weber and Rinne tests were normal.

Even against medical advice, it was the patient's decision to cease rivaroxaban after attending the Emergency Department. Two weeks after the initial event, the tympanic membrane was normal and no symptoms were reported.

\section{DISCUSSION}

The tympanic membrane (TM) arterial supply is divided in two parts, towards its outer and inner aspects. The deep auricular branch of maxillary artery supplies the outer aspect of the TM. The inner surface is supplied in its anterior quadrants by the anterior tympanic branch of the maxillary artery and posteriorly by the stylomastoid branch of the posterior auricular artery. Branches of the middle meningeal artery also supply the TM. These vessels form anastomosis in the lamina propria and are organized into

\footnotetext{
1. Department of Otorhinolaryngology. Centro Hospitalar de S. João. Porto. Portugal.

2. Department of Surgery \& Physiology/Otorhinolaryngology. Faculty of Medicine. University of Porto. Porto. Portugal.

$\square$ Autor correspondente: Inês Saldanha. mariainessaldanha@gmail.com

Recebido: 17 de julho de 2017 - Aceite: 30 de agosto de 2018 | Copyright @ Ordem dos Médicos 2019
} 


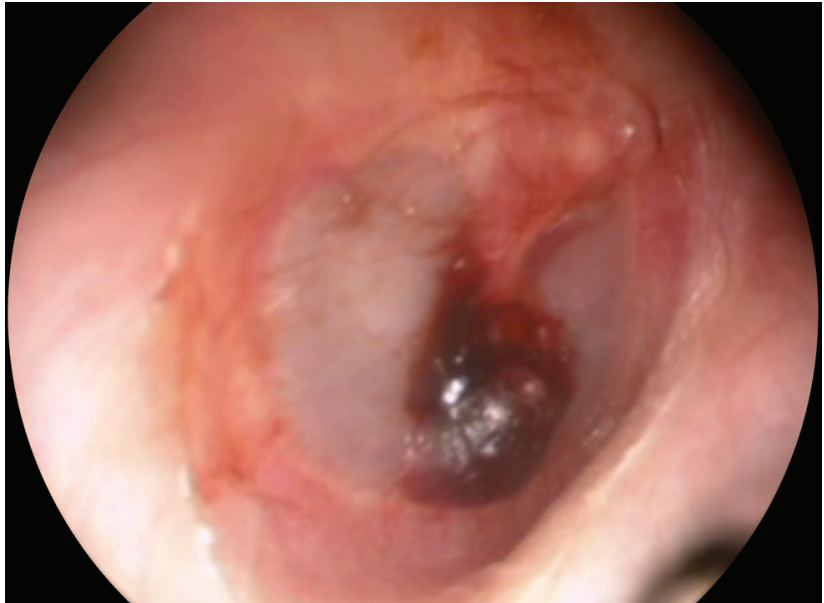

Figure 1 - Haematoma of the inferior quadrants of the right tympanic membrane

a peripheral ring with arteries radiating to the centre of the tympanic membrane. ${ }^{10}$

There is a tight pressure equilibrium between the outer and middle ear with constant minor pressure equalizations. The intricate artery supply and the movements associated with sound transmission and pressure equalization can, associated with anticoagulation, predispose to minor bleeding in areas of arterial fragility.

This event brings to discussion the question of safety in the administration of rivaroxaban. Despite the knowledge that these drugs may cause epistaxis or gastrointestinal bleeding ${ }^{11,12}$ among several other haemorrhagic side effects, the authors were not able to find any documented description of tympanic haemorrage. The potential side effects of rivaroxaban are not entirely known, so the administration of rivaroxaban should be judicious.

Otoscopy is a simple medical diagnostic procedure that can be used by general practitioners and other generalist clinicians so that they could detect a tympanic haemorrhage.

\section{REFERENCES}

1. Furugohri T, Isobe $\mathrm{K}$, Honda $\mathrm{Y}$, Kamisato-Matsumoto $\mathrm{C}$, Sugiyama N Nagahara T, et al. DU-176b, a potent and orally active factor Xa inhibitor: in vitro and in vivo pharmacological profiles. J Thromb Haemost. 2008; 6:1542-49.

2. Perzborn E, Strassburger J, Wilmen A, Pohlmann J, Roerhig S, Schlemmer $\mathrm{KH}$, et al. In vitro and in vivo studies of the novel antithrombotic agent BAY 59-7939--an oral, direct Factor Xa inhibitor. J Thromb Haemost. 2005; 3:514-21.

3. Pinto DJ, Orwat MJ, Koch S, Rossi KA, Alexander RS, Smallwood A, P. et al. Discovery of 1-(4-methoxyphenyl)-7-oxo-6-(4-(2-oxopiperidin-1-yl) phenyl)-4,5,6,7-tetrahydro-1H-pyrazolo[3,4-c]pyridine-3-carboxamide (apixaban, BMS-562247), a highly potent, selective, efficacious, and orally bioavailable inhibitor of blood coagulation fa. J Med Chem. 2007; 50:5339-56.

4. Roehrig S, Straub A, Pohlmann J, Lampe T, Pernerstorfer J, Schlemmer $\mathrm{KH}$, et al. Discovery of the novel antithrombotic agent 5-chloro- $\mathrm{N}-(\{(5 \mathrm{~S})$ 2-oxo-3- [4-(3-oxomorpholin-4-yl)phenyl] -1,3-oxazolidin-5-yl\} methyl) thiophene- 2-carboxamide (BAY 59-7939): an oral, direct factor $\mathrm{Xa}$ inhibitor. J Med Chem. 2005; 48: 5900-8.

5. Beyer-Westendorf J, Forster K, Pannach S, Ebertz F, Gelbricht V, Thieme $\mathrm{C}$, et al. Rates, management, and outcome of rivaroxaban bleeding in daily care: results from the Dresden NOAC registry. Blood. 2014;124:955-62.

6. Tamayo S, Frank Peacock W, Patel M, Sicignano N, Hopf KP, Fields
The differential diagnosis includes bullous myringitis. However, the patient presented with mild otalgia and no fever. The healthy appearance of the tympanic membrane, without suspicion of acute otitis media, also supports an isolated heamorrage of the tympanic membrane.

\section{CONCLUSION}

There has been an increasing use of the new oral anticoagulant drugs in the management of thromboembolic conditions. Nevertheless, the full range of secondary events is yet to be established, as demonstrated in the present clinical report.

\section{PROTECTION OF HUMANS AND ANIMALS}

The authors declare that the procedures were followed according to the regulations established by the Clinical Research and Ethics Committee and to the Helsinki Declaration of the World Medical Association.

\section{DATA CONFIDENTIALITY}

The authors declare having followed the protocols in use at their working center regarding patients' data publication.

\section{PATIENT CONSENT}

Obtained.

\section{CONFLICTS OF INTEREST}

All authors report no conflict of interest.

\section{FUNDING SOURCES}

This research received no specific grant from any funding agency in the public, commercial, or not-for-profit sectors.

LE, et al. Characterizing major bleeding in patients with nonvalvular atrial fibrillation: a pharmacovigilance study of 27467 patients taking rivaroxaban. Clin Cardiol. 2015;38:63-8.

7. Steinberg BA, Blanco RG, Ollis D, Kim S, Holmes DN, Kowey PR, et al. Outcomes Registry for Better Informed Treatment of Atrial Fibrillation II: rationale and design of the ORBIT-AF II registry. Am Heart J. 2014;168:160-7.

8. Kakkar AK, Mueller I, Bassand JP, Fitzmaurice DA, Goldhaber SZ Goto $S$, et al. International longitudinal registry of patients with atrial fibrillation at risk of stroke: Global Anticoagulant Registry in the FIELD (GARFIELD). Am Heart J. 2012;163:13-9.

9. Gloria AF. Global registry on long-term oral anti-thrombotic treatment in patients with atrial fibrillation (.hase II/II). [accessed 2015 Sep 15). Available from: https://clinicaltrials.gov/ct2/show/NCT01468701.

10. Hamberger CA, Wersall J. Vascular supply of the tympanic membrane and the ossicular chain. Acta Otolaryngol. 1974; 57:308-18.

11. Pahs $L$, Beavers $C$, Schuler $P$. The real-world treatment of hemorrhages associated with dabigatran and rivaroxaban: a multicenter evaluation. Crit Pathw Cardiol. 2015;14:53-61.

12. Boland $M$, Murphy $M$, Murphy $M$, McDermott E. Acute-onset severe gastrointestinal tract hemorrhage in a postoperative patient taking rivaroxaban after total hip arthroplasty: a case report. J Med Case Rep. 2012;6:129. 